\title{
ARTICLE 3 OF THE UNIFORM COMMERCIAL CODE
}

\author{
ROBERT J. LYNN*
}

\section{INTRODUCTION}

Article 3 of the Uniform Commercial Code has been described as a significant improvement on the Negotiable Instruments Law. It is more concise. ${ }^{2}$ It eliminates incongruities in the older statute. ${ }^{3}$ It gives an explicit rule in many instances where the NIL is obscure and the case law divergent. 4

Those descriptive statements are accurate, and article 3 is probably better than its veteran counterpart. But adjectives like "daring" and "bold" are more properly reserved for other articles. All the vexing questions raised under the NIL are not resolved by the Code. On the contrary, the same vague language that understandably invited controversy in the past appears conspicuously in the new statutes $^{\mathscr{E}}$ for the very good reason that generalized expressions encompass workable ideas. The firm adherence to established notions explains the relatively mild furor ${ }^{6}$ accompanying the evolution of

* Professor of Law, Ohio State University.

1 "[T] $T$ he best commercial law the world has ever seen": Hawkland (speaking of the Uniform Commercial Code in general), "Sales and Documents of Title," in Short Course on the Uniform Commercial Code 15 (1960).

2 Hawkland, Commercial Paper (Negotiable Instruments-Under the Uniform Commercial Code) (1959). Professor Hawkland's handbook is one of the series published by the Joint Committee on Continuing Legal Education of the American Law Institute and the American Bar Association.

3 E.g., NIL $\S 36$ states that an indorsement is restrictive which either prohibits the further negotiation of the instrument or constitutes the indorsee the agent of the indorser or vests the title in the indorsee in trust for or to the use of some other person. NIL $\S 47$ states that an instrument negotiable in its origin continues to be negotiable until it has been restrictively indorsed. If $\$ 47$ were applied literally, an instrument specially indorsed in trust for some person other than the special indorsee would not thereafter be negotiable, in that all equities available against the restrictive indorser would be let in against subsequent purchasers. That view of $\$ 47$ has been rejected. Britton, Bills and Notes 170 (2d ed. 1961) (hereinafter cited BRITTON). UCC \& 3-206(1) states that no restrictive indorsement prevents further negotiation of the instrument.

4 Under the NIL it is not clear that a payee may qualify as a holder in due course. BRITTON at 308. UCC \$ 3-302(2) states that a payee may be a holder in due course.

5 E.g., UCC \& 3-302 in defining a holder in due course states that he takes "in good faith."

6 Of the living American authorities on commercial law, Beutel, editor of the current edition of Brannon's Negotiable Instruments Law, is most outspoken in his condemnation of the Code. Beutel, "The Proposed Uniform (?) Commercial Code Should not Be Adopted in Ohio," 14 Ohio St. L.J. 3 (1953). Britton has prepared four articles 
article 3 and justifies characterizing it the least controversial of the substantive articles in the Commercial Code. ${ }^{7}$

An article by Dean Andrews comparing the NIL with article 3, with special reference to the Ohio cases, appeared in an earlier issue of this Journal when the text of the Uniform Commercial Code had attained substantially its current form. ${ }^{8}$ Only minimal changes in the text of article 3 having been made in the revisions of the past decade, ${ }^{9}$ and since the reported Ohio NIL cases in the nine years since Professor Andrews' comprehensive survey appeared few, ${ }^{10} \mathrm{I}$ shall not attempt to duplicate his earlier work. Rather, I shall try to describe the structure of article 3 and to show by example the kinds of problems it purports to resolve and the types of difficulties left untouched (or largely so) by the Code.

\section{Format}

Like the NII, Article 3 of the Commercial Code groups related sections under captions such as "Transfer and Negotiation"11 and "Presentment, Notice of Dishonor and Protest."12 But unlike the NIL, ${ }^{13}$ article 3 has no separate titles dealing exclusively with bills of

comparing the NIL with Article 3: "Formal Requisites of Negotiability-The Negotiable Instruments Law Compared with the Proposed Commercial Code," 26 Rocky Mt. L. Rev. 1 (1953); "Transfers and Negotiations Under the Negotiable Instruments Law and Article 3 of the Uniform Commercial Code," 32 Texas L. Rev. 153 (1953); "Holder in Due Course-A Comparison of the Provisions of the Negotiable Instruments Law with Those of Article 3 of the Proposed Commercial Code," 49 Nw.U.L. Rev. 417 (1954); "Defenses, Claims of Ownership and Equities-A Comparison of the Provisions of the Negotiable Instruments Law with Corresponding Provisions of Article 3 of the Proposed Commercial Code," 7 Hastings L.J. 1 (1955).

7 "[B]asically there is no fundamental change in the Negotiable Instruments section . . . ." Leary, "Commercial Paper," in Short Course on the Uniform Commercial Code 87, 89 (1960).

8 Andrews, "Should Article 3 of the Uniform Comercial Code be Adopted in Ohio?" 14 Ohio St. L.J. 32 (1953).

8 I do not imply that the revisions were inconsequential. E.g., in the 1952 official draft $\$ 3-307$ (3) read: After evidence of a defense has been introduced a person claiming the rights of a holder in due course has the burden of establishing that he or some person under whom he claims is in all respects a holder in due course. In the 1957 official text \& 3-307(3) reads: After it is shown that a defense exists a person claiming the rights of a holder in due course has the burden of establishing that he or some person under whom he claims is in all respects a holder in due course.

10 Surveys of recent case law by Dean Andrews are available in 4 W. Res. L. Rev. 246 (1953), 5 id. 289 (1954), 6 id. 275 (1955), 9 id. 349 (1958), 10 id. 431 (1959), 11 id. 411 (1960), and 12 id. 543 (1961). See generally, Callahan, "Negotiable Instruments," 40 Ohio Jur. 2d 1 (1959).

11 UCC \$\$ 3-201-3-208.

12 UCC \$\$ 3-501-3-511.

13 Title II-Bills of Exchange, Title III-Promissory Notes and Checks. 
exchange or promissory notes. Drafts ${ }^{14}$ are distinguished from checks or notes or certificates of deposit only where differentiation is thought preferable. ${ }^{15}$ Unless separability is achieved, generality of treatment obtains. ${ }^{18}$ Article 3 does not apply to money, documents of title or investment securities, ${ }^{17}$ and article 3 is subject to article 4 on bank deposits and collections and article 9 on secured transactions. ${ }^{18}$ Article 1 must be consulted for definitions and principles of construction..$^{19}$

Like the NIL, article 3 is a mixture of specificity and generality. If case law reached an undesirable result under the NIL, the Code often changes the law. ${ }^{20}$ If case law was divergent under the NIL, the Code frequently states a preference, and, indeed, some sections consist almost exclusively of listed preferences. ${ }^{21}$ The same drafting technique was used by Crawford when he compiled the NII sixty-five

14 UCC $\$ 3-104$ (2) (a). "Draft" is preferred to "bill of exchange."

15 See UCC \& 3-411 "Certification of a Check."

16 E.g., UCC $\$ 3-114(1)$ reads: The negotiability of an instrument is not affected by the fact that it is undated, antedated or postdated.

17 UCC \& 3-103(1).

18 UCC' $\$ 3-103(2)$. UCC $\$ 4-205(1)$ reads: A depositary bank . . . may supply any indorsement of the customer which is necessary to title unless the item contains the words "payee's indorsement required" or the like. In the absence of such a requirement a statement placed on the item by the depositary bank to the effect that the item was deposited by a customer or credited to his account is effective as the customer's indorsement.

10 UCC \& 3-102(4). UCC \& 3-307 states that under some circumstances a signature is prestmed to be genuine or authorized. UCC \& 1-201(31) reads: "Presumption" or "presumed" means that the trier of fact must find the existence of the fact presumed unless and until evidence is introduced which would support a finding of its nonexistence.

20 In Shemonia v. Verda, 24 Ohio App. 246, 157 N.E. 717 (1927), the Court of Appeals for Lorain County found that the following instrument contained a promise to pay:

Cleveland, Ohio, January 2, 1924

I borrowed money from Petros Shemonia, the sum of five hundred dollars $(\$ 500.00)$ with 4 per cent interest. The borrowed money ought to be paid within four months from above date.

Witness: Piroske Verda.

[signed] Vassili Malik Verda

The instrument being one for the unconditional payment of money only, it fell within the terms of $\S 11334$, General Code (now \& 2309.32, R.C.). There was no allegation that it was negotiable in form and the NIL was not cited. UCC \$ 3-102(1)(c) reads: A "promise" is an undertaking to pay and must be more than an acknowledgment of an obligation.

21 See UCC $\$$ 3-105 ("When Promise or Order Unconditional") and 3-106 ("Sum Certain"). 
years ago. ${ }^{22}$ Therefore, those consulting article 3 can expect explicit answers to some questions. Other questions that might have been answered explicitly are determined by examining a number of related sections and studying the applicable comments. ${ }^{23}$ Only tentative answers to still other questions are invited by the Code, and some problems on commercial paper are not touched by the Code at all.

\section{Illustrative Problems}

To show how article 3 reforms existing law, clarifies questionable inferences, at times falls short of stating a definitive rule, and mixes substance and procedure, let us consider four illustrative questions on defenses, joinder of parties, taking in due course, and trial procedure, in that order.

\section{Non-delivery of an Incomplete Instrument}

Suppose that D, who maintains a checking account at the $\mathrm{X}$ Bank, signs his name as drawer to a blank check furnished its customers by the X Bank. $\mathrm{D}$ puts the incomplete instrument in what he thinks to be a safe place. It is stolen, completed, and transferred to an innocent purchaser for value without notice of the theft or unauthorized completion. Having been informed by $\mathrm{D}$ of the theft of the check, the $\mathrm{X}$ Bank (drawee) refuses to pay the check when it is presented for payment. Does D, as drawer, have under the NII a defense good even against the innocent purchaser? Section 15 reads as follows:

Where an incomplete instrument has not been delivered it will not, if completed and negotiated, without authority, be a valid contract in the hands of any holder, as against any person whose signature was placed thereon before delivery.

Section 15 states a real defense, a defense effective against a holder in due course in the absence of an estoppel. ${ }^{24}$ Had D completed the check before it was stolen, his failure to relinquish possession voluntarily is a personal defense under the $\mathrm{NIL},{ }^{25}$ ineffective against a holder in due course ${ }^{26}$ and, likewise, had $\mathrm{D}$ voluntarily relinquished

22 See NIL $\S \S 2$ ("Certainty as to Sum") and 5 ("Additional Provisions not Affecting Negotiability").

23 E.g., under the NIL $\S \S 14$ and 52(1), a holder who acquired an instrument incomplete as to some material term could not qualify as a holder in due course. BRITTON at 283. Under the UCC such a holder may qualify. \$\$ 3-302(1), 3-304(1) (a), 3-304 (4) (d) ; § 3-304, Comment 10.

24 BRITTON at 204.

$25 \S 16$ reads in part: . . . where the instrument is in the hands of a holder in due course, a valid delivery thereof by all parties prior to him so as to make them liable to him is conclusively presumed.

28 BRITTON at 201. 
possession of the incomplete check, its subsequent unauthorized completion and transfer to an innocent purchaser for value without notice of the unauthorized completion is a personal defense ${ }^{27}$ under the NIL. ${ }^{28}$ There being no persuasive reason for differentiating nondelivery of an incomplete instrument from either non-delivery of a complete instrument or delivery of an incomplete instrument, section 3-115 of the Code reverses the rule of section 15 of the NIL. Comparable successful efforts to require like results in analogous kinds of cases are found throughout article $3 .^{29}$ Inconsistencies in the law either dictated or permitted by the NIL are appreciably reduced by the Code.

\section{Joinder of Parties}

Suppose an indorsee of a negotiable promissory note decides to sue the maker on his promise to pay and prior indorsers on their contracts to pay. May the plaintiff over timely objection join the maker and the indorsers as defendants in one action? If in such a case the plaintiff does not in the first instance join the maker and the indorser, may a defendant indorser, as a third-party plaintiff, over timely objection implead as third-parties defendant prior indorsers and the maker against whom the indorser initially chosen by the plaintiff as defendant has an "action over" if found liable on his contract to pay?

Although substantive law sections of the NII suggest the possibility of joinder of defendants at the option of the plaintiff and impleader of third-party defendants at the option of the defendant indorser, no section explicitly answers either question posed above. Ohio Revised Code section 2307.22 reads as follows:

One or more of the persons severally liable on an instrument may be included in the same action thereon.

Commentators assert that joinder of the maker and indorsers at the option of the plaintiff is permissible under such a statute; although there appears to be no Ohio case law precisely in point, cases else-

27 Id. at 199.

28 \$ 14 reads in part: But if any such [incomplete] instrument, after completion, is negotiated to a holder in due course, it is valid and effectual for all purposes in his hands, and he may enforce it as if it had been filled up strictly in accordance with the authority given and within a reasonable time.

29 For example, suppose that $M$ signs his name as maker to a negotiable promissory note blank as to the amount and the name of the payee. $M$ delivers the incomplete instrument to $\mathrm{X}$ with instructions to fill it in for an amount not exceeding a particular sum. If $\mathrm{X}$ completes the instrument in violation of the instructions given, under the NIL a holder in due course can in an action against $M$ enforce the instrument as completed. NIL § 14; BRITTON at 199. But had M completed the note himself, a holder in due course could in an action against $M$ enforce the instrument according to its 
where support authoritative commentary. ${ }^{30}$ Like the NIL, article 3 leaves the question of permissive joinder of defendants at the option of the plaintiff to local law.

What of impleader of third-party defendants by the defendant indorser? An earlier version of Ohio Revised Code section 2307.22 reads as follows:

Persons severally liable upon the same obligation or instrument, including the parties to bills of exchange or promissory notes, may, all or any of them, be included in the same action, at the option of the plaintiff. ${ }^{31}$

Does the absence of explicit language in the re-enactment of the statute permit the inference that joinder of defendants is permissible at the option of the plaintiff and that impleader of third-party defendants is permissible at the option of the defendant indorser? Although there seems to be no Ohio case law precisely in point, judicial interpretation of the forerunner of section 2307.22 suggests that the right to implead prior parties is not given to the defendant indorser. ${ }^{32}$

original tenor if the amount were raised after issue. NIL $\S 124$; BRITTON at 671 . And this, generally speaking, even though the maker completed the note in such a way as to facilitate alteration. BRITTON at 662 . Article 3 treats the two situations in the same way. UCC $\S 3-115,3-406$, and $3-407$. $\S 3-406$ reads as follows: Any person who by his negligence substantially contributes to a material alteration of the instrument or to the making of an unauthorized signature is precluded from asserting the alteration or lack of authority against a holder in due course or against a drawee or other payor who pays the instrument in good faith and in accordance with the reasonable commercial standards of the drawee's or payor's business.

Under § $3-406$, a maker who "substantially contributes" to the material alteration is liable to the holder in due course of the instrument as altered just as the maker who delivers an incomplete instrument is liable to the holder in due course of the instrument as completed.

30 See Clark on Code Pleading 386 n. 167 (2d ed. 1947). The Ohio cases citing $\S 2307.22$ or its forerunner, $\S 38$ of the Code of Civil Procedure of 1853 , are usually actions involving joint makers of an instrument, or the principal and the surety, or the maker and the guarantor. Neil v. Board of Trustees of the Ohio Agricultural and Mechanical College, 31 Ohio St. 15 (1877) (action against maker and guarantor); Brotherhood of Railway Clerks Nat. Bank v. DuBois, 10 Ohio L. Abs. 473 (Ohio Ct. App. 1931) (action against joint makers); General Construction Co.gv. Village of Lakewood, 17 Ohio C. C. R. (n.s.) 165, 32 Ohio C. C. Dec. 88 (1910) (action against surety, principal intervenes). An exception is Kautzman v. Weirick, 26 Ohio St. 330 (1875) (action against maker and payee-guarantor ["substantially the same as ... an indorser"]).

$31 \S 38$ of the Code of Civil Procedure, 2 Rev. Stat. of Ohio 957 (Swan \& Critchfield 1860).

$32 \S 2307.22$ first appeared as $\S 38$ of the Code of Civil Procedure of 1853 and read as follows: Persons severally liable upon the same obligation or instrument, including the parties to bills of exchange and promissory notes, may, all or any of them, be in- 
None of the Federal Rules is directed specifically to joinder of parties severally liable on a written instrument. But Federal Rule 20 reads in part as follows:

[P]ersons may be joined . . . as defendants if there is asserted against them ... severally . . any right to relief in respect of or arising out of the same transaction ... or series of transactions ... and if any question of ... fact common to all of them will arise in the action. ${ }^{33}$

Although invoking Federal Rule 20 is not explicitly limited to parties plaintiff, allowance under the Rules for "Third-Party Practice" makes it clear that Rule 20 operates at the option of the plaintiff and it is in that respect comparable to Ohio Revised Code section 2307.22. ${ }^{34}$

Rule 14(a) reads in part as follows:

[A] defendant may move . . . for leave as a third-party plaintiff to serve a summons and complaint upon a person not a party to the action who is or may be liable to him for all or part of the plaintiff's claim against him. ${ }^{35}$

Rule 14(a) clearly permits the defendant indorser to implead as

cluded in the same action, at the option of the plaintiff. Curwen's Laws of Ohio in Force 1169 (1854). In the revision of 1878 the statute took its current form, 75 Laws of Ohio 607 (1878) and became $\S 5009$ of the Revised Statutes of Ohio (Daugherty, Brasee, and Okey 1879). Before 1853 there were relevant statutes covering specific kinds of cases. E.g., in 3 Revised Statutes of Ohio 1883 (Chase 1835 ): $\S 2 \ldots$ any person . . . having a right to demand any sum of money, upon any protested bill of exchange [may bring] an action ... against the drawers or indorsers, jointly or severally, or against either of them separately .... In an action brought under $\S 38$ when joinder was explicitly at the option of the plaintiff, an attempt of a defendant surety to make the principal debtor a party defendant by cross petition was unsuccessful. Wilkins v. The Ohio National Bank, 31 Ohio St. 565 (1878). If the defendant surety cannot join his principal over the objection of the plaintiff, a defendant indorser should not be permitted to bring in the maker as a party defendant over the objection of the plaintiff.

\$ 2307.19 of the Ohio Revised Code reads as follows: Any person may be made a defendant who has or claims an interest in the controversy adverse to the plaintiff, or who is a necessary party to a complete determination or settlement of a question involved therein.

In construing $\S 2307.19$, the Common Pleas Court of Franklin County said, "... the persons who are made defendant... must be those whose presence is essential to the determination of the controversy before the Court, and where the defendant in the original controversy seeks to have another person made a defendant and to inject new issues into the action by way of cross petition against such other party in an effort to litigate matters wholly between themselves and which cannot affect the right of the plaintiff to recover on his petition, the application of such original defendant should be denied . . . " Gilligan v. Prudential Life Ins. Co., 70 Ohio L. Abs. 225, 231 (1954).

33 Fed. R. Civ. P. 20.

343 Moore's Federal Practice $\$ 20.06$ (2d ed. 1948).

35 Fed. R. Civ. P. 14. 
third-party defendants prior parties liable to him. Ohio has no statute authorizing third-party practice. Section 3-803 of the Code gives the defendant indorser a procedural advantage heretofore available to him only on a common law basis. ${ }^{36}$ It reads as follows:

Notice to Third Party.

Where a defendant is sued for breach of an obligation for which a third person is answerable over under this Article he may give the third person written notice of the litigation, and the person notified may then give similar notice to any other person who is answerable over to him under this Article. If the notice states that the person notified may come in and defend and that if the person notified does not do so he will in any action against him by the person giving the notice be bound by any determination of fact common to the litigations, then unless after reasonable receipt of the notice the person notified does come in and defend he is so bound.

Suppose that $P$, the payee-indorser of a negotiable promissory note, is sued on his contract to pay. $P$ concedes that his signature is genuine, but alleges that the amount of the instrument was raised after he negotiated it. The plaintiff remote party controverts the allegation of material alteration and alleges that he is a holder in due course with respect to the defendant. If the note has not been altered at any time, the payee-indorser, having been found liable on his contract to pay the amount sought by the remote party plaintiff, has an action over against the maker, and he is logically entitled to a judgement in the amount for which he himself was found liable. ${ }^{37}$ If the maker is a party to the action brought by the plaintiff remote party against the payee-indorser, he is bound by the finding of fact on the disputed issue

36 Dayton Fabricated Steel Co. v. Dayton Town \& Country, Inc., 99 Ohio App. 309,133 N.E.2d 423 (1954), recognizes the right of an indemnitee to "vouch in" his indemnitor when the latter by contract has agreed to defend any and all suits brought against the former arising out of accidents incident to the performance of a construction project by the indemnitor for the indemnitee. That the right to indemnity is contingent on the giving of timely notice to the indemnitor by the indemnitee is conceded in The Globe Indemnity Co. v. Schmitt, 142 Ohio St. 595, 53 NE.2d 790 (1944) and Maryland Casualty Co. v. Frederick Co., 142 Ohio St. 605, 53 N.E.2d 795 (1944); Restatement, Judgments § 107(a) (1942).

37 Evidence introduced by the plaintiff remote party in the first action might support a finding that both the signature of the maker and the material parts of the body of the note (including the amount) were completed contemporaneously by the same person and not tampered with thereafter. If so, then a concession or finding of identity between the ostensible maker and the person sued as maker by the payee in an "action over" requires that the maker be held liable to the plaintiff payee in the same amount for which the payee-indorser was held liable when sued by the remote party. Otherwise the hoped-for identity between juridically-found fact and "true" fact is lost sight of and in one of the two cases there has been a miscarriage of justice. 
of material alteration. ${ }^{38}$ If he is not a party, then under the NIL the maker, when sued by the payee-indorser, can again make material alteration an issue, and if the trier of fact were to find for the defendant maker on that issue, the maker would not be liable in the amount for which the plaintiff payee-indorser had himself been found liable, and, in fact, the maker would be discharged on the instrument altogether ${ }^{39}$ unless the plaintiff payee qualified as a holder in due course with respect to the maker. In that event the maker would be liable "according to [the] original tenor." 40

Section 3-803 of the Code is not an equivalent of Rule 14(a) ${ }^{41}$ but in our assumed case it serves the payee-indorser equally well with respect to settling the disputed issue of material alteration and making the finding binding upon the maker. ${ }^{42}$ Quite apart from the desirability of having the same disputed issue of fact resolved in the same way where the evidence is the same in both cases, the defendant payee-indorser, having borne some of the cost of resolving the disputed issue of fact, ought not to be put to additional expense for the same purpose a second time in another action. The fact that in the second action against the maker the payee's position with respect to the fact of alteration is not the same as it was when the payee was sued by the remote party is irrelevant, for under section 3-803 the payee, having informed the maker that he will be bound by the fact determination in the first action, invites a finding of fact on the disputed issue of material alteration which will be final between the payee and the maker. ${ }^{43}$

38 Restatement, Judgments \& 68(1) (1942).

30 NIL § 124.

40 Ibid.

41 Fed. R. Civ. P. 14(a).

42 Invoking $\$ 3-803$ does not assure impleading the maker. Consequently the payeeindorser may still have to proceed against the maker in a second action at a later time.

43 Suppose a maker of a negotiable promissory note refuses to pay at maturity because the maker has been informed by the payee-indorser that the holder seeking payment procured the instrument by fraud in the inducement practiced on the payee. NIL $\$ 88$ reads as follows: "Payment is made in due course when it is made at or after the maturity of the instrument to the holder thereof in good faith and without notice that his title is defective." [Emphasis supplied.] Despite $\$ 88$ it is not clear under the NII that the maker when sued by the holder could effectively interpose the payee's claim ("jus tertii") as a bar to recovery. BRITTON at 468. \$ 3-603(1) of the Code discharges the maker who pays with knowledge of the payee-indorser's claim unless prior to such payment the payee supplies adequate indemnity to the maker or enjoins payment in an action in which the payee-indorser and holder are parties. If the payeeindorser neither supplies adequate indemnity nor intervenes, could the defendant maker through § 3-803 make the payee-indorser's claim a disputed issue of fact in the action between the holder and the maker, and obtain a finding binding upon the payeeindorser in any subsequent action between the payee-indorser and the maker? Hawkland 


\section{Taking in Due Course}

Suppose an action by a remote party against the maker of a negotiable promissory installment note purchased by the plaintiff after the due date of one or more installments of principal, but prior to the due date of one or more additional installments. The maker has a personal defense such as fraud in the inducement, but the plaintiff's being a holder in due course of the note with respect to installments of principal falling due after his acquisition ${ }^{44}$ does not turn on actual knowledge of the defense. Rather, there being one or more installments of principal past due when the plaintiff takes, does that circumstance in itself preclude the plaintiff from qualifying as a holder in due course? If that circumstance in itself does not disqualify, does the fact that the note shows on its face that one or more installments have matured, but which shows no notation of payments of installments, give notice to the plaintiff of the default of the maker?

With respect to the first question, the Ohio Court of Appeals for Cuyahoga County said in Harvard Mtg. Co. v. Neeson:

It is clear that two installments of $\$ 75.00$ each were then due. These unpaid installments alone were sufficient to attach to the instrument its character as a dishonored note. The rule is too well fixed to warrant quoting the authorities or to indulge in the refinements and distinctions of particular cases. ${ }^{45}$

The court does not say that the plaintiff knew or even had reason to know that the installments were unpaid. The opinion does note that

seems to imply that he could, Hawkland, Commercial Paper (Negotiable InstrumentsUnder the Uniform Commercial Code) 92 (1959), but he may not intend his generalized statement to cover the kind of case put. The Comment to \& 3-803 implies that the defendant maker could not "vouch in" the payee-indorser because the latter is not "answerable over" to the former. In any event, whether or not the defendant maker can "vouch in" the payee-indorser, § 3-603(1) discharges him although he pays with knowledge of the payee's claim. Therefore it is the holder who has a particular interest in knowing whether the defendant maker can delay payment by invoking \& 3-803.

Suppose a maker of a negotiable promissory note refuses to pay at maturity solely because the maker has been informed by the payee-indorser that a transferee procured a negotiation from the payee by fraud in the inducement and the holder seeking payment acquired the note with knowledge of that fraud. Again, $\$ 3-603(1)$ discharges the maker although he pays with knowledge of the payee's claim. Under the NII the holder's acquisition with knowledge of the payee's claim might be critical if the maker had a personal defense of his own. Fehr v. Campbell, $288 \mathrm{~Pa} .549,137$ Atl. 113 (1927); contra, Baird v. Lorenz, 57 N.D. 804, 224 N.W. 206 (1929) ("But there is nothing on the face of the note to suggest fraud against the maker and this is the fraud which casts doubt on the good faith of the purchaser."). Under the UCC such knowledge appears to disqualify the holder from taking in due course. \$ 3-302(1) (c).

$44 \mathrm{He}$ cannot be a holder in due course with respect to installments due and unpaid at acquisition. As to them he takes a note that is "overdue."

456 Ohio L. Abs. 577 (1928). 
he had "no actual notice of infirmities" in the note. Since the defendant interposed fraud in the inducement as a bar to recovery by the plaintiff, it is permissible to infer that the "infirmities" referred to encompassed only the fraud. If so, then the plaintiff was disqualified from being a holder in due course simply because the maker was in default in two installments when the plaintiff acquired the note.

Section 52 of the NII provides in part that to qualify as a holder in due course a taker must "in good faith," instrument which is "complete and regular upon its face"47 before it is "overdue, and without notice that it [has] been previously dishonored" ${ }^{\prime 48}$ if such is the fact. As Britton points out, ${ }^{49}$ the plaintiff in a case like that put cannot be said to have taken an instrument "overdue" as regards installments not due at acquisition. Therefore, he is disqualified from being a holder in due course under the NIL because he is deemed to have notice of the defense. What puts him on notice? In the Neeson case, nothing-or at least nothing mentioned in the opinion.

How does article 3 deal with the problem? No section gives a specific answer, but consulting several sections permits a fairly confident answer.

The requirements of section $52(1)$ of the NIL having been condemned, ${ }^{50}$ section 3-302(1) of the Code, defining a holder in due course, reads as follows:

A holder in due course is a holder who takes the instrument

(a) for value; and

(b) in good faith; and

(c) without notice that it is overdue or has been dishonored or of any defense against or claim to it on the part of any person.

But no remarkable change has been made in the law, for completeness and regularity are now a matter of notice under the Code, section 3-304(1)(a) reading as follows:

The purchaser has notice of a claim or defense if the instrument

is so incomplete, bears such visible evidence of forgery or altera-

46 NIL $\S 52(3)$.

47 NIL $\S 52(1)$.

48 NIL $\S 52(2)$.

49 BRITTON at 275.

50 NIL $\S 52$ reads in part: A holder in due course is a holder who has taken the instrument under the following conditions:

1. That it is complete and regular on its face .... "... under section 52(1) ... the holder . . . is bluntly told, virtually as a matter of law, that, if the instrument was incomplete or irregular, he is not a holder in due course no matter how innocent in fact he was." BRITTON at 289. 
tion, or is otherwise so irregular as to call into question its validity, terms or ownership or to create an ambiguity as to the party to pay. ...

\section{And section 3-304(3) (a) states:}

The purchaser has notice that an instrument is overdue if he has reason to know that any part of the principal amount is overdue. . . .

Under the Code, then, a taker is not disqualified from being a holder in due course with respect to future installments unless he has notice that one or more prior installments are due and unpaid at acquisition. The rule of the Neeson case is reversed, and Traynor's notion that even knowledge of non-payment of past due installments would not necessarily disqualify a holder from taking in due course with respect to future installments is rejected. ${ }^{51}$

When does a taker have notice of the "dishonor" of an installment note (as in the Neeson case) ${ }^{52}$ or notice that the instrument is

51 "If the principles set forth in the Uniform Negotiable Instruments Act are applied ... knowledge that the first installments were not paid would not as a matter of law prevent plaintiffs from being holders in due course. It would merely be evidence that plaintiffs might not have acquired the notes in good faith." Bliss v. California Co-op. Producers, 30 Cal. 2d 240, 264, 181 P.2d 369, 383 (1947) (Traynor, J., dissenting). The appearance of the installment notes at the time of acquisition is not made clear in any of the reported opinions in the Bliss case. In 154 P.2d 929 (1945) the California Third District $\mathrm{Ct}$. of Appeals held that no installment was in default at acquisition and that the plaintiffs held in due course. The same court in 156 P.2d 259 (1945) when modifying its earlier opinion held that acquisition of an installment note after one or more installments have become due does not in itself disqualify one from taking in due course as regards future installments. On appeal the Supreme Court of California in 172 P.2d 62 (1946) held that acquisition of an installment note after one or more installments have become due disqualifies one from taking in due course regardless of whether or not the past due installments have been paid, but on a rehearing the court retreated from that untenable position and beld that acquisition of an installment note after one or more installments have become due does not disqualify one from taking in due course as regards future installments unless one or more past due installments have not been paid and the taker has notice of that fact. The installment notes in litigation had been negotiated as collateral security. The secured note having listed the face amounts of the installment notes, the court held that this circumstance warranted an inference that past due installments had not been paid and ordered a retrial of the issue of notice. 30 Cal. 2d 240, 248, 181 P.2d 369, 374 (1947). Ultimately it was held that the plaintifis took with notice of the default in payment of past due installments and therefore did not hold in due course. 112 Cal. App. 2d 507, 247 P.2d 85 (1952).

52 The Ohio court said the note was "dishonored" when taken by the plaintiff rather than "overdue." But despite the word choice, the court treated the instrument as "overdue" or "matured" when taken, there being no reference to facts giving the plaintiff notice of dishonor, and under NIL $\$ 52(2)$ prior dishonor in itself does not disqualify a taker from being a holder in due course. That failure to pay installments of principal as they fall due renders the instrument in its entirety "overdue" is the position 
"overdue" (to use the expression preferred by the Code)? The Code in section 1-201(25) says in part:

A person has "notice" of a fact when from all the circumstances known to him at the time in question he has reason to know that it exists.

Does the fact that the note shows on its face that one or more installments have matured at acquisition, but which shows no notation of payments of installments, give the taker notice of the default of the maker with respect to past due installments so as to disqualify the taker from being a holder in due course with respect to future installments? Note that in this kind of case the form of the note may invite notations or it may not.

If the note shows on its face that one or more installments have matured at acquisition and have been paid (that being the fact), but which also shows that one or more additional installments have matured at acquisition, and with respect to them there is no notation of payment or non-payment, does that give the taker notice of the default in fact of the maker? Again the form of the note may invite notations or it may not. Can we decide the question of notice more easily in this case if we know that the taker paid an amount for the note greater than the sum of the future installments? Does the answer now appear so clear that the question of notice is no longer for the jury? ?3 $^{53}$

Although article 3 answers analogous questions on notice, ${ }^{54}$ it does not explicitly codify solutions to the problems on installment notes just posed. In this respect the UCC once again parallels the NII.

\section{Trial Procedure}

(a) Under the NIL

Implicit in the NIL is the notion that the classic action on a negotiable instrument-the suit by a remote party against maker, drawer or prior indorser-will be tried in a logical fashion, with the introduction of the evidence bearing on disputed issues of fact

taken in the Neeson case and that point of view has support. Aigler, Cases on Bills and Notes 344 n. 56 (2d ed. 1955).

53 To decide when the question of notice becomes a matter of law we need information on purchases of notes for an amount greater than the sum of the future installments. Of every hundred, what proportion are prompted by a desire to hold the maker's note? What proportion are motivated by a desire to get a particular interest rate? How frequently do such buyers suspect that an installment of principal is past due?

54 E.g., § 3-304(4) (f) states that knowledge of a default in the payment of interest does not of itself give the purchaser notice of a defense or claim. 
controlled by the trial judge in such a way that its sufficiency can be tested at appropriate points by the motion for a directed verdict. For example, NII section 59 reads as follows:

Every holder is deemed prima facie to be a holder in due course; but when it is shown that the title of any person who has negotiated the instrument was defective, the burden is on the holder to prove that he or some person under whom he claims acquired the title as holder in due course. But the last-mentioned rule does not apply in favor of a party who became bound on the instrument prior to the acquisition of such defective title.

Assume an action by a remote party against a maker of a negotiable promissory note in which the plaintiff is conceded to be a holder with respect to the defendant and the disputed issues of fact are: (1) Does the defendant have a defense of fraud in the inducement practiced by the payee on the maker in procuring the note? (2) Is the plaintiff a holder in due course with respect to the maker? If the evidence bearing on the disputed issues of fact is presented in the order suggested by section 59 , the plaintiff makes out a prima facie case against the defendant by introducing the instrument into evidence. The defendant then introduces evidence bearing on the defense of fraud in the inducement. At this point the sufficiency of the defendant's evidence could be tested by the plaintiff's motion for a directed verdict. If reasonable minds could not find from the evidence that the defense of fraud exists, the plaintiff's motion should be granted, ${ }^{55}$ for plaintiff does hold the defendant's instrument and is entitled to payment in the absence of a defense irrespective of whether the plaintiff is a holder in due course. ${ }^{56}$ The words "when it is shown" in section 59 are not the equivalent of "when evidence is introduced tending to show." ${ }^{\text {"N7 }}$ But if the plaintiff's motion for a directed verdict is overruled, the plaintiff at that point in the proceedings has a choice: he can rest his case, hoping that the trier of fact will find that no defense of fraud in the inducement exists; for if it so finds, he is

55 Hamden Lodge No. 517, Independent Order of Odd Fellows v. Ohio Fuel Gas Co., 127 Ohio St. 469,189 N.E. 246 (1934). In the state courts of Ohio no statute specifically regulates the motion for a directed verdict. Ball, Materials on Trial Practice 198 (rev. temp. ed. 1960). Federal Rule 5a(a) reads as follows: A party who moves for a directed verdict at the close of the evidence offered by an opponent may offer evidence in the event that the motion is not granted, without having reserved the right so to do and to the same extent as if the motion had not been made. A motion for a directed verdict which is not granted is not a waiver of trial by jury even though all parties to the action have moved for directed verdicts. A motion for a directed verdict shall state the specific grounds therefor.

56 Lile's Bigelow on Bills, Notes, and Checks at 31 (3d rev. ed. 1928).

57 BRITTON at 255. 
entitled to judgment. If it finds that there was fraud, he loses, for the "presumption" that he is a holder in due course under such circumstances avails him nothing; there being a finding that fraud occurred, the plaintiff to prevail must be a holder in due course, ${ }^{58}$ and no evidence bearing on that disputed issue of fact has been put before the trier of fact. Therefore, having unsuccessfully moved for a directed verdict after the defendant introduced his evidence on fraud, the plaintiff unwilling to risk an adverse finding with respect to the defense will introduce evidence tending to show that he is a holder in due course.

Do lawsuits in Ohio under the NIL proceed in the way suggested? They may, for there is nothing in the Ohio case law which precludes moving for a directed verdict before all the evidence is in. ${ }^{59}$ But authoritative information answering the question is slight, and it is conceivable that the orderly testing of the sufficiency of the evidence at periodic points in the trial does not exist in practice. Lawyers think of a civil trial as proceeding in three main stages: the plaintiff's case, the defendant's case, and the plaintiff's rebuttal. In Ohio, the pleadings substantiate the notion: the plaintiff's petition ${ }^{60}$ (amended if need be) ${ }^{61}$ states his case; the defendant's answer ${ }^{62}$ states his case; the plaintiff's reply ${ }^{63}$ controverts the defendant's answer. In our case assumed above, the plaintiff might introduce evidence at the outset tending to show that he is a holder in due course of the defendant's instrument, for should the plaintiff's being a holder in due course become essential to recovery, the risk of non-persuasion on that issue is on the plaintiff. Likewise, if the defendant has evidence tending to show that the plaintiff is not a holder in due course, the defendant might introduce it after presenting his evidence bearing on the defense of fraud in the inducement; and the defendant almost certainly would do so if the plaintiff had opened his case by introducing evidence bearing on being a holder in due course. The plaintiff in rebuttal tries to patch up his case as best he can. He may introduce evidence tending to show that the defense of fraud does not exist and that the defendant's evidence with respect to holding in due course is unreliable.

If the trying of the case proceeds in the fashion just suggested,

58 Id. at 261.

59 That the motion is appropriately made at the conclusion of the plaintiff's case is assumed in Cincinnati Traction Co. v. Durack, 78 Ohio St. 243, 85 N.E. 38 (1908).

c0 Ohio Rev. Code § 2309.04.

61 Ohio Rev. Code $\$ 2309.34$.

62 Ohio Rev. Code $\$ 2309.13$.

63 Ohio Rev. Code \$ 2309.24. 
using the motion for a directed verdict to test the sufficiency of the evidence gets obscured by the disorder. If the defendant moves for a directed verdict after the plaintiff at the outset has introduced evidence bearing on holding in due course, the motion should be overruled because at that point in the trial there is no evidence with respect to the defense of fraud, and we do not know whether the plaintiff must be a holder in due course in order to recover. If the plaintiff moves for a directed verdict after the defendant has introduced evidence bearing on both the defense and the plaintiff's status as a holder in due course, the ruling on the motion should be made solely on the sufficiency of the evidence bearing on the defense; for it is not until all the evidence is in, and either the plaintiff or the defendant or both have moved for a directed verdict, that the judge can properly consider the sufficiency of the evidence with respect to both of the disputed issues of fact.

In any event, whatever the order of the presentation of the evidence, section 59 of the NIL does not explicitly dictate trial procedure. That being. so, what does it do?

Section 59 gives us a rule to apply when facts are conceded, stipulated or found. If the plaintiff is a holder in due course, he is entitled to judgment if there is a defense cut off by negotiation, such as fraud in the inducement. Section 59 states where the risks of non-persuasion and the burdens of going forward lie. In our hypothetical case, the defendant bears the risk of non-persuasion with respect to the disputed issue of fraud and he must go forward with the evidence bearing on fraud or a verdict will be directed against him. Instructions can be requested and a charge framed on the basis of the substantive rules stated in section 59 .

\section{(b) Under the Code}

The mix of substantive and procedural language is continued in the UCC. For example, section 3-307(1) sensibly requires a specific denial of the genuineness of a signature before its validity is put in issue and section 3-307(1) (b) sensibly gives the proponent a presumption of genuineness (with stated exceptions) when the effectiveness of a signature is put in issue. The presumption squares with common experience ${ }^{64}$ and is unexceptionable. But it can be rebutted, and therefore section 3-307(2) says that when signatures are "admitted or established, production of the instrument entitles a holder to recover on it unless the defendant establishes a defense." [Emphasis supplied.] Comment 1 to section 3-307 indicates that a finding of genuineness is required unless the adversary supports his

64 UCC \$3-307, Comment 1. 
denial with evidence sufficient to warrant a finding in his favor. Neither the Commercial Code nor the Comments purport to deal with authentication generally. Is it proper to assume that under the Code the proponent whose only obstacle to the admissibility of an instrument into evidence is a specific denial of the genuineness of the defendant's signature is entitled over objection to admission on the strength of the presumption alone? It would seem so. Section 3-307(2) means that when signatures are admitted to be genuine or are found to be genuine, a verdict for the plaintiff is required unless the trier finds that there is a defense. That is a rule of substantive law. That defendant bears the risk of non-persuasion with respect to his defense is encompassed in "... unless the defendant establishes. ..." "[P] roduction of the instrument" has nothing to do with authentication, for at the conclusion of the plaintiff's evidence (including the instrument itself) bearing on genuineness, the trial judge under the Code must admit the instrument into evidence if his inspection shows an instrument consistent with the proponent's pleadings and evidence, bearing a signature coinciding with the defendant's name. There is no occasion at that point in the proceedings to talk of genuineness being "established," for after all of the evidence bearing on genuineness is in, and has withstood a motion for a directed verdict (if such a motion is made), the trier of fact may find that the disputed signature is a forgery.

And so it goes. Article 3, like the NIL, tries to do a number of things with just a few words. Allegations in the pleadings, the order in which the evidence is offered, the burden of going forward, the risk of non-persuasion, authentication, substantive rules on recovery, bases for instructions and the charge-all are alluded to in section 3-307, and the lawyer is invited to sort the functions for himself, aided to some extent by the Comments.

\section{Concluston}

The four questions considered on defenses, joinder, taking in due course, and trial procedure do not exhaust the inquiries opened by article 3 , but they do demonstrate that reform is achievable through an imperfect instrument. The structure of article 3 is not above criticism. But its obvious shortcomings explain its general acceptability: this mishmash of specificity and vague generality, this mixture of substance and procedure seems familiar. And it is familiar, because it is the NIL refurbished.

Article 3 may be amended. It may be supplemented. Certainly it will be interpreted, and uniformity of interpretation is unlikely. But article 3 as enacted will work. After all, its counterpart has been working for fifty years. 